\title{
The effect of manuring with undersown catch crop, and production system on the potato tuber content of microelements
}

\author{
Anna Płaza, Barbara Gąsiorowska, Emilia Rzążewska, Anna Cybulska, Rafał Górski \\ Agrotechnology Department, Faculty of Natural Sciences, Siedlce University of Natural Sciences \\ and Humanities, Poland
}

\begin{abstract}
The potato tuber content of microelements is lower than that of macroelements but they are equally important. With this respect, there has been noticed a favourable effect of natural and organic manuring. The objective of the study reported here was to determine the effect of manuring with an undersown catch crop, either autumn-incorporated or left on the soil surface as mulch for spring incorporation, and production system on the potato tuber content of microelements. The study involved a field experiment, which was conducted in 2009-2012. The following two factors were examined: I - manuring with undersown catch crop: control, farmyard manure, Persian clover, Persian clover + westerwolds ryegrass, westerwolds ryegrass, Persian clover - mulch, Persian clover + westerwolds ryegrass - mulch, westerwolds ryegrass mulch; II - production system: integrated and organic. Potato tubers were sampled to determine microelement contents. The highest iron and zinc contents were recorded in the tubers of potato manured with autumn-incorporated Persian clover whereas boron content was the highest in the tubers of potato manured with Persian clover, regardless of when it had been incorporated, as well as an autumn-incorporated Persian clover + westerwolds ryegrass mixture. Organic potatoes contained more iron and boron whereas tubers grown in the integrated production system were higher in zinc, manganese and copper. Potato manuring with undersown catch crops and farmyard manure in both the production systems studied increased the potato tuber content of microelements, excluding copper and manganese.
\end{abstract}

\footnotetext{
Correspondence: Emilia Rzążewska, Agrotechnology Department, Faculty of Natural Sciences, Siedlce University of Natural Sciences and Humanities, 14 Prusa Steet, 08-110 Siedlce, Poland.

Tel.: +48256431237 .

E-mail: emilia.rzazewska@uph.edu.pl

Key words: Manuring with undersown catch crop; microelements; mulch; potato; production system.

Received for publication: 9 October 2018.

Revision received: 7 March 2019.

Accepted for publication: 13 March 2019.

(C) Copyright: the Author(s), 2019

Licensee PAGEPress, Italy

Italian Journal of Agronomy 2019; 14:1343

doi:10.4081/ija.2019.1343

This article is distributed under the terms of the Creative Commons Attribution Noncommercial License (by-nc 4.0) which permits any noncommercial use, distribution, and reproduction in any medium, provided the original author(s) and source are credited.
}

\section{Introduction}

The potato tuber content of microelements is lower compared with macroelements but microelements are equally important as they form part of enzymes, which activate a number of biochemical processes (Hajšlovă et al., 2005; Roma et al., 2017; Sierra et al., 2017; Mengist et al., 2018). The soil content of minerals depends on the type of parental rock, decomposed organic matter as well as agro-technological factors including manuring (Baranowska et al., 2017; Garrido et al., 2017). In this respect, there has been noticed a favourable effect of natural and organic manuring (Redulla et al. 2005; Płaza et al., 2015; Makarewicz et al., 2018). Farmyard manure is basic natural manure applied in potato cultivation. As farmyard manure production is continually declining, the development of integrated and organic potato production encourages farmers to include more catch crops in the rotation process (Płaza et al., 2015). In the aforementioned agricultural systems undersown catch crops may be the main biomass source used instead of farmyard manure in potato fertilisation (Dabney et al., 2001; Makarewicz et al., 2018). There are no Polish studies on the influence of green manures applied in different production systems on the potato tuber content of microelements, hence the need arises to conduct this type of research. The objective of the study reported here was to determine the effect of manuring with undersown catch crops, either autumn-incorporated or left on the soil surface as mulch for spring incorporation, as well as production system on the potato tuber content of microelements.

\section{Materials and methods}

Field research was carried out at the Zawady Experimental Farm, which belongs to Siedlce University of Natural Sciences and Humanities and spanned the years 2009-2012.

The soil of the experiment was Albic Luvisol, soil valuation class IVa representing the very good rye complex of agricultural soil suitability. The soil content of available minerals was as follows: P $5.23 \mathrm{mgkg}^{-1}, \mathrm{~K} 11.56 \mathrm{mgkg}^{-1}, \mathrm{Mg} 5.57 \mathrm{mgkg}^{-1}$, Mn 116 $\mathrm{mgkg}^{-1}, \mathrm{Cu} 1.6 \mathrm{mgkg}^{-1}$, B $0.52 \mathrm{mgkg}^{-1}, \mathrm{Zn} 7.3 \mathrm{mgkg}^{-1}$, Fe 659 $\mathrm{mgkg}^{-1}$. The soil reaction was neutral and humus content amounted for $1.39 \%$. The experiment was set up as a split-block arrangement of plots with three replicates. Two factors were examined: I - manuring with undersown catch crop: control (no manuring with undersown catch crop), farmyard manure $\left(30\right.$ tha $\left.^{-1}\right)$, Persian clover (seed sowing rate of $18 \mathrm{kgha}^{-1}$ ), Persian clover + westerwolds ryegrass (seed sowing rate of $9+10 \mathrm{kgha}^{-1}$ ), westerwolds ryegrass (seed sowing rate of $20 \mathrm{kgha}^{-1}$ ), Persian clover - mulch (seed sowing rate of $18 \mathrm{kgha}^{-1}$ ), Persian clover + westerwolds ryegrass - mulch (seed sowing rate of $9+10 \mathrm{kgha}^{-1}$ ), westerwolds 
ryegrass - mulch (seed sowing rate of $20 \mathrm{kgha}^{-1}$ ); II - production system: integrated and organic.

In autumn, the fresh matter yield of undersown catch crops (including roots to the depth of $30 \mathrm{~cm}$ ) was determined in an area of $1 \mathrm{~m}^{2}$ in each plot. The average yield across three years in the integrated production system was: 28.3 tha $^{-1}$ of Persian clover, 32.7 tha $^{-1}$ of the Persian clover + westerwolds ryegrass mixture, 36.4 tha $^{-1}$ of westerwolds ryegrass, the respective yields in the organic system being: 23.7 tha $^{-1}, 26.9$ tha $^{-1}$ and 28.1 tha $^{-1}$.

Spring triticale grown for grain was undersown with catch crops, which preceded table potato. Mineral fertilisers were applied to the whole experimental area under the integrated production system. The per 1 ha rates of the fertilisers were as follows: $90 \mathrm{~kg} \mathrm{~N}, 36.9 \mathrm{~kg}$ P and $99.6 \mathrm{~kg} \mathrm{~K}$. The rates were adjusted to soil availability as well as quantity of expected yields. In plots, which had been ploughed before winter, spring-applied mineral fertilisers were mixed with soil using a cultivator with an attached harrow. In the mulched plots, mulch was incorporated by means of a disc harrow followed by a cultivator. In the organic production system, mineral fertilisation was replaced by farmyard manure, which was applied at the rate of 30 tha $^{-1}$ to the whole area of organic plots prior to cultivation of spring triticale, which was undersown with catch crops. Potatoes were planted in late April and harvested in mid-September. Integrated production system involved an application of mechanical and chemical control of weeds, diseases and pests. Prior to emergence, potatoes were hilled and harrowed every seven days and, immediately before emergence, sprayed with a herbicide mixture of Afalon $50 \mathrm{WP}+$ Reglone Turbo $200 \mathrm{SL}$ (1 kg $\left.+1 \mathrm{dm}^{3} \mathrm{ha}^{-1}\right)$. Colorado potato beetle was controlled using two applications of Fastac $\left(0.1 \mathrm{dm}^{3} \mathrm{ha}^{-1}\right)$ and late potato blight was controlled by means of two applications of the fungicide Ridomil $\mathrm{MZ}$ WP $\left(2 \mathrm{dm}^{3} \mathrm{ha}^{-1}\right)$. In the organic production system, weeds were removed mechanically. Colorado potato beetle was controlled by two applications of Novodor SC $\left(2.5 \mathrm{dm}^{3} \mathrm{ha}^{-1}\right)$, and late potato blight using three applications of Miedzian $50 \mathrm{WP}\left(4 \mathrm{kgha}^{-1}\right)$. During potato harvest, samples were taken in each plot to determine microelements. $\mathrm{Cu}, \mathrm{Fe}, \mathrm{Mn}, \mathrm{Zn}$ and $\mathrm{B}$ contents were determined in the dry matter of potato tubers by means of inductively coupled plasma optical emission spectrometry (ICP-OES).

Each of the characteristics studied was analysed by means of ANOVA for the split-block arrangement. Comparison of means for significant sources of variation was achieved by means of Tukey's test at the significance level of $P \leq 0.05$. All the calculations were performed in STATISTICA ${ }^{\circledR}$, version 12.0 and MS Excel.

\section{Results}

The years of conducting the research were characterised by a varied course of weather conditions (Table 1). In 2010, the highest sum of precipitation was highest at the highest average temperature, which adversely affected the content of micronutrients in potato tubers. By contrast, in 2011 the smallest sum of precipitation was recorded, at medium temperature approximated to the long-term average, which had a positive effect on the accumulation of micronutrients in potato tubers. In 2012, a slightly higher sum of precipitation was recorded than in 2011, with a more beneficial distribution of precipitation in the growing seasons of potato, which translated into a higher concentration of micronutrients in tubers.

The potato tuber content of copper differed significantly due to the influence of the experimental factors, and was significantly affected by their interaction (Table 2). The highest copper content was determined in tubers harvested from control plots where only mineral fertilisation has been applied. The potato manured with farmyard manure and undersown catch crops significantly reduced the potato tuber content of copper. The lowest concentration of this element was determined in the tubers of potato manured with autumn-incorporated Persian clover. In the remaining plots manured with undersown catch crops, copper content in potato tubers was not significantly different from copper concentration determined in the tubers of potato following farmyard manure application. The production system significantly affected the potato tuber content of copper, which was lower in organic potatoes. The lowest copper content was recorded in the tubers of organic potato following undersown catch crops and farmyard manure, and the highest in control tubers, which had been produced using mineral fertilisers in the integrated production systems.

Statistical analysis demonstrated a significant effect of experimental factors on the potato tuber content of iron, and a significant interaction between these factors (Table 3). The lowest concentration of iron was recorded in the tubers of control potato followed mineral fertilisers. Farmyard manure and undersown catch crops contributed to an increase in the potato tuber content of iron. The highest iron content was recorded in the tubers of potato manured with Persian clover, which had been ploughed down in autumn. Iron content in the tubers of potato following an autumn-incorporated mixture of Persian clover and westerwolds ryegrass as well as Persian clover mulch was not significantly different from iron

Table 1. Weather conditions in the growing season of potato according to the Zawady Metorological Station.

\begin{tabular}{|c|c|c|c|c|c|c|c|}
\hline \multirow[t]{2}{*}{ Year } & \multicolumn{6}{|c|}{ Month } & \multirow[t]{2}{*}{ Mean } \\
\hline & April & May & June & July & August & September & \\
\hline \multicolumn{8}{|l|}{ Mean air temperature, ${ }^{\circ} \mathrm{C}$} \\
\hline 2010 & 8.9 & 14.0 & 17.4 & 21.6 & 19.8 & 11.8 & 15.6 \\
\hline 2011 & 10.1 & 13.4 & 18.1 & 18.3 & 18.0 & 14.4 & 15.4 \\
\hline 2012 & 8.9 & 14.6 & 16.3 & 20.7 & 18.0 & 14.1 & 15.4 \\
\hline Long-term (15 yr) mean & 8.2 & 14.2 & 17.6 & 19.7 & 19.1 & 12.9 & 15.3 \\
\hline \multicolumn{8}{|l|}{ Rainfall sum, mm } \\
\hline 2010 & 10.7 & 93.2 & 62.6 & 77.0 & 106.3 & 109.9 & 459.7 \\
\hline 2011 & 31.0 & 36.1 & 39.1 & 120.2 & 18.6 & 12.0 & 257.0 \\
\hline 2012 & 29.9 & 53.4 & 76.2 & 43.0 & 51.0 & 11.4 & 264.9 \\
\hline Long-term (15 yr) mean & 37.4 & 47.1 & 48.1 & 65.5 & 43.5 & 47.3 & 288.9 \\
\hline
\end{tabular}


content determined in the tubers of potato following farmyard manure application. In the remaining plots, iron concentration was significantly lower than in potato tubers following farmyard manure treatment, it was higher than values determined in control tubers. The production systems significantly affected iron content in potato tubers. Tubers issued from organic potato following green manures and farmyard manure application, contained significantly higher iron content with respect to potato grown under integrated production system. Interactions between the experimental factors were examined. It has been found that the highest iron concentration was recorded in organic potato tubers manured with autumn-incorporated Persian clover, and the lowest in the control potato tubers produced under integrated production system.

Manganese content in potato tubers was significantly affected by the experimental factors and their interaction (Table 4). The highest manganese concentration was determined in control potato tubers. Manganese content in potato tubers manured with undersown catch crops, apart from westerwolds ryegrass left as mulch on the soil surface for spring incorporation, was significantly lower with respect to those obtained in potato tubers following farmyard manure application. The production system also significantly influenced the potato tuber manganese content. Higher manganese concentrations were recorded in potato tubers produced under integrated system compared to those from organic production system. Interactions between the experimental factors indicated that man- ganese content was the lowest in potato tubers from the integrated production system, manured with Persian clover either incorporated in autumn or left as mulch on the soil surface for spring incorporation and the highest was obtained for control potato tubers grown under integrated production system.

Statistical analysis demonstrated also a significant effect of the experimental factors and their interaction on zinc content in potato tubers (Table 5). The lowest zinc concentration was recorded in control potato tubers harvested from the plots where only mineral fertilisers were applied. Manuring of potato with farmyard manure and undersown catch crops, which provide potato plants with macro- and microelements, increased the zinc content in potato tubers. The highest zinc content was recorded in the potato tubers manured with autumn-incorporated Persian clover. In the remaining plots manured with undersown catch crops, the zinc tuber content was not significantly different from potato tubers following farmyard manure application. The production system showed a significant effect on zinc content in potato tubers. A higher zinc concentration was recorded in the potato tubers grown under integrated production system. Interactions between different factors were examined and indicated that the highest zinc content was noted in the potato tubers manured with autumn-incorporated Persian clover and an autumn-incorporated mixture of Persian clover and westerwolds ryegrass, as well as Persian clover left on the soil surface for further spring incorporation. It was the lowest

Table 2. Copper content in potato tubers (means over 2010-2012), $\mathrm{mg} \mathrm{kg}^{-1} \mathrm{~d} . \mathrm{m}$.

\begin{tabular}{|c|c|c|c|}
\hline Manuring with undersown catch crop & F & & Mean \\
\hline & Integrated farming & Organic farming & \\
\hline Control & 4.967 & 4.645 & 4.806 \\
\hline Farmyard manure & 4.732 & 4.517 & 4.625 \\
\hline Persian clover & 4.619 & 4.436 & 4.527 \\
\hline Persian clover + westerwolds ryegrass & 4.676 & 4.487 & 4.582 \\
\hline Westerwolds ryegrass & 4.721 & 4.495 & 4.608 \\
\hline Persian clover - mulch & 4.625 & 4.483 & 4.554 \\
\hline Persian clover + westerwolds ryegrass - mulch & 4.683 & 4.499 & 4.591 \\
\hline Westerwolds ryegrass - mulch & 4.730 & 4.504 & 4.670 \\
\hline Mean & 4.719 & 4.508 & - \\
\hline $\mathrm{LSD}_{0.05}$ & & & \\
\hline Manuring with undersown catch crop & 0.075 & & \\
\hline Production system & 0.070 & & \\
\hline Interaction & 0.092 & & \\
\hline
\end{tabular}

Table 3. Iron content in potato tubers (means over 2010-2012), $\mathrm{mg} \mathrm{kg}^{-1} \mathrm{~d} . \mathrm{m}$.

\begin{tabular}{lccc} 
Manuring with undersown catch crop & \multicolumn{3}{c}{ Production system } \\
& Integrated farming & Organic farming \\
Control & 42.27 & 44.32 & 43.30 \\
Farmyard manure & 50.68 & 52.12 & 51.40 \\
Persian clover & 53.74 & 54.89 & 54.32 \\
Persian clover + westerwolds ryegrass & 49.65 & 50.72 & 50.19 \\
Westerwolds ryegrass & 45.32 & 46.40 & 51.25 \\
Persian clover - mulch & 50.21 & 52.28 & 48.90 \\
Persian clover + westerwolds ryegrass - mulch & 48.36 & 49.44 & - \\
Westerwolds ryegrass - mulch & 44.27 & 45.69 & \\
Mean & 48.06 & 49.48 & \\
LSD & & & \\
Manuring with undersown catch crop & & & \\
Production system & & & \\
Interaction & & & \\
\hline
\end{tabular}


in control tubers grown under both the integrated and organic production systems. Boron content in potato tubers was significantly affected by the experimental factors and their interaction (Table 6). The concentration of this element was the lowest in control potato tubers following mineral fertilisation. Green manures and farmyard manure increased the boron content in potato tubers. Boron concentration was the highest in the potato tubers manured with autumn-incorporated Persian clover and autumn-incorporated mixture of Persian clover and westerwolds ryegrass as well as Persian clover mulch. Boron content in potato tubers manured with a spring-incorporated mixture of Persian clover and westerwolds ryegrass applied as mulch differed insignificantly from the content determined in potato tubers following farmyard manure application. Boron content was significantly lower only in potato tubers following westerwolds ryegrass application, regardless the application date of the cover crop. Nevertheless, Boron levels were higher than those recorded for control tubers. The production system significantly affected the potato tuber boron content, the highest concentration was recorded in organic potato tubers. Interactions between the experimental factors indicated that the highest boron content was found in potato tubers manured with autumn-incorporated Persian clover under organic production system, and the lowest was obtained in control tubers grown under integrated production system.

\section{Discussion}

\section{Copper content}

Potato tubers provide valuable micronutrients necessary for human nutrition (Snapp et al., 2005; Musilova et al., 2016; Roma et al., 2017). In the present research, the higher copper content was recorded in the tubers of potato tubers issued from control plots where only mineral fertilisers were applied. Our result are in line with those of Braun et al. (2011) and Sajed et al. (2015) who reported a higher copper content in the tubers of potato treated with mineral fertilisers. In the present study, potato manured with farmyard manure and undersown catch crops significantly reduced the copper content of potato tubers. Snapp et al. (2005) highlighted that potatoes manured with vermicompost and green manures exhibited lower potato tubers copper contents. In the present research, the lowest copper content was recorded in the tubers produced under organic system. This finding is in line with those reported by Hajšlovă et al. (2005) and Wierzbowska et al. (2018). It should be explained by the fact that in the organic potato production system under the influence of using only organic fertilisation, the activation of microflora and soil fauna takes place, which helps to absorb certain metabolic compounds. As a result, there is a balanced collection of ions, including a smaller amount of copper,

Table 3. Iron content in potato tubers (means over 2010-2012), $\mathrm{mg} \mathrm{kg}^{-1} \mathrm{~d} . \mathrm{m}$.

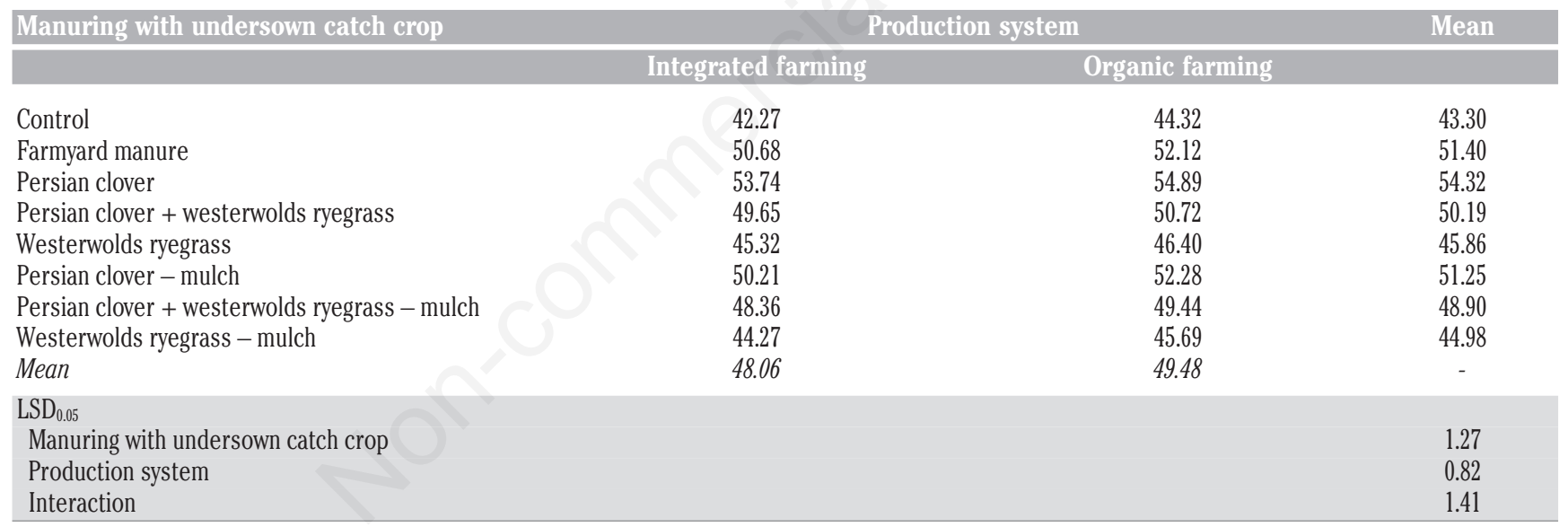

Table 4. Manganese content in potato tubers (means over 2010-2012), $\mathrm{mg} \mathrm{kg}^{-1} \mathrm{~d} . \mathrm{m}$.

\begin{tabular}{lccc} 
Manuring with undersown catch crop & \multicolumn{2}{c}{ Production system } \\
& Integrated farming & Organic farming \\
Control & & 8.514 & 8.631 \\
Farmyard manure & 8.747 & 8.345 & 8.439 \\
Persian clover & 8.532 & 8.014 & 8.123 \\
Persian clover + westerwolds ryegrass & 8.139 & 8.220 & 8.077 \\
Westerwolds ryegrass & 8.240 & 8.083 \\
Persian clover - mulch & 8.327 & 8.197 \\
Persian clover + westerwolds ryegrass - mulch & 8.198 & 8.289 \\
Westerwolds ryegrass - mulch & 8.290 & 8.223 \\
Mean & 8.387 & 8.274 \\
LSD 0.05 & 8.358 & 8.141 \\
Manuring with undersown catch crop & & 8.244 \\
Production system & & - \\
Interaction & & 0.0838 \\
\hline
\end{tabular}


which in turn determines a more positive chemical composition of potato tubers than in an integrated production system, where mineral fertilisers are used in addition to organic fertilisers.

\section{Iron content}

The lowest concentration of iron was recorded in the control tubers produced under mineral fertiliser application. This finding agrees with results reported by Braun et al. (2011), Hadi et al. (2014) as well as Roma et al. (2017). Farmyard manure and undersown catch crops contributed to increase the iron content in potato tubers due to the fact that the biomass of both farmyard manure and green manures incorporated into the soil was an additional source of macro- and microelements available for the plants (Musilova et al., 2016; Garrido et al., 2017). Tubers produced under organic farming system following green manures and farmyard manure application contained higher iron content compared to potato tubers produced under integrated production system. This finding matches the results reported by Hajšlovă et al. (2005), Wang et al. (2008), Hunter et al. (2011) and Wierzbowska et al. (2018).

\section{Manganese content}

The highest manganese concentration was determined in the control potato tubers. Similarly to findings by Braun et al. (2011),
Hadi et al. (2014) and Ashrafzadeh et al. (2017). Green manures and farmyard manure significantly reduced potato tuber manganese content, which was also confirmed by Braun et al. (2011), White et al. (2009), Sierra et al. (2017). Higher manganese content was found in potato tubers produced under integrated production system with respect to those produced under organic management, similarly to findings by Sawicka et al. (2016) and Wierzbowska et al. (2018). This is due to the fact that the organic potato production system uses only organic fertilisation, such as catch crops, spent mushroom substrate or vermicompost, which improve the biological, chemical and physical properties of the soil, including increasing the organic carbon content and cation exchange capacity. In addition, they increase the uptake of iron from the soil by the potato plant, also increasing its concentration in the soil. The iron content in potato tubers from organic farming is higher than from conventional or integrated cultivations, where mineral fertilisation is applied.

\section{Zinc content}

The lowest zinc concentration was recorded in the potato tubers harvested from control plots where only mineral fertilisers were applied. Also research by White et al. (2009), Braun et al. (2011), Hadi et al. (2014), Ashrafzadeh et al. (2017) as well as Baranowska et al. (2017) similarly demonstrated that the lowest

Table 5. Zinc content in potato tubers (means over 2010-2012), $\mathrm{mg} \mathrm{kg}^{-1} \mathrm{~d} . \mathrm{m}$.

\begin{tabular}{|c|c|c|c|}
\hline Manuring with undersown catch crop & & & Mean \\
\hline & Integrated farming & Organic farming & \\
\hline Control & 11.02 & 10.18 & 10.60 \\
\hline Farmyard manure & 12.64 & 11.77 & 12.21 \\
\hline Persian clover & 13.97 & 12.44 & 13.21 \\
\hline Persian clover + westerwolds ryegrass & 13.19 & 12.26 & 12.73 \\
\hline Westerwolds ryegrass & 12.34 & 11.97 & 12.16 \\
\hline Persian clover - mulch & 13.22 & 12.51 & 12.87 \\
\hline Persian clover + westerwolds ryegrass - mulch & 12.70 & 11.86 & 12.28 \\
\hline Westerwolds ryegrass - mulch & 12.11 & 11.33 & 11.72 \\
\hline Mean & 12.65 & 11.79 & - \\
\hline $\mathrm{LSD}_{0.05}$ & & & \\
\hline Manuring with undersown catch crop & & & 0.67 \\
\hline Production system & & & 0.49 \\
\hline Interaction & & & 0.88 \\
\hline
\end{tabular}

Table 6. Boron content in potato tubers (means over 2010-2012), $\mathrm{mg} \mathrm{kg}^{-1} \mathrm{~d} . \mathrm{m}$.

\begin{tabular}{|c|c|c|c|}
\hline Manuring with undersown catch crop & & & Mean \\
\hline & Integrated farming & Organic farming & \\
\hline Control & 4.527 & 4.636 & 4.582 \\
\hline Farmyard manure & 5.229 & 5.365 & 5.297 \\
\hline Persian clover & 5.523 & 5.729 & 5.626 \\
\hline Persian clover + westerwolds ryegrass & 5.287 & 5.470 & 5.379 \\
\hline Westerwolds ryegrass & 5.023 & 5.189 & 5.106 \\
\hline Persian clover - mulch & 5.438 & 5.593 & 5.516 \\
\hline Persian clover + westerwolds ryegrass - mulch & 5.185 & 5.334 & 5.260 \\
\hline Westerwolds ryegrass - mulch & 4.921 & 5.062 & 4.992 \\
\hline Mean & 5.142 & 5.297 & - \\
\hline $\mathrm{LSD}_{0.05}$ & & & \\
\hline Manuring with undersown catch crop & & & 0.061 \\
\hline Production system & & & 0.043 \\
\hline Interaction & & & 0.085 \\
\hline
\end{tabular}


zinc concentration was measured in potato tubers produced under mineral fertilisers treatments. Manuring of potato with farmyard manure and undersown catch crops, which provide potato plants with macro- and microelements, increased the zinc content of potato tuber. This finding agrees with reports by Redulla et al. (2005), Baranowska et al. (2017) and Roma et al. (2017). The higher zinc concentration was recorded in the tubers of potato cultivated in the integrated production system. A similar finding was reported by Hajšlovă et al. (2005), Wszelaki et al. (2005) and Wang et al. (2008). It should be explained by the fact that in the organic potato production system only organic fertilisation is used, such as green manure, spent mushroom substrate or vermicompost, which increase the content of organic matter in the soil, and thus reduces the uptake of elements harmful to human health, including manganese by potato plants. In contrast, mineral fertilisation is also used in the integrated potato production system, which increases the manganese content in potato tubers.

\section{Boron content}

The concentration of boron was the lowest in the control potato tubers produced following mineral fertilisation. A similar relationship was found by Sayed et al. (2015) and Osvalde et al. (2016). The highest boron concentration was obtained for potato tubers manured with autumn-incorporated Persian clover and an autumnincorporated mixture of Persian clover and westerwolds ryegrass as well as Persian clover mulch. Snapp et al. (2005), Sayed et al. (2015) as well as Osvalde et al. (2016), reported similar findings where green manures and vermicompost increased the concentration of boron in potato tubers. The highest boron concentration being recorded in the tubers of organic potato system. A similar relationship was found by Hajšlovă et al. (2005), Griffiths et al. (2012) as well as Wierzbowska et al. (2018).

To sum up, it should be stated that in the conducted experiment, green manure and farmyard manure increased the content of iron, zinc and boron in potato tubers, and decreased the content of copper and manganese. Also, the potato production system also significantly altered the content of micronutrients in tubers.

\section{Conclusions}

The highest iron and zinc contents were recorded in the tubers of potato manured with autumn-incorporated Persian clover, and the highest boron content in the tubers of potato manured with Persian clover, regardless of the incorporation date, as well as an autumn-incorporated mixture of Persian clover and westerwolds ryegrass. By contrast, undersown catch crops and farmyard manure contributed to a decline in the potato tuber content of copper and manganese. Organic potato tubers contained more iron and boron whereas tubers produced in the integrated production system exhibited higher zinc, manganese and copper contents. In both the production systems, potato manuring with undersown catch crops and farmyard manure increased the tuber content of microelements, excluding copper and manganese contents.

\section{References}

Ashrafzadeh S, Gaw S, Genet R, Glover CN, Leung DWM, 2017. Natural variation in correlations between cadmium and micronutrients in potato tubers. J. Food Com. Anal. 59:55-60.
Baranowska A, Zarzecka K, Gugała M, Mystkowska I, 2017. Contents of zinc, copper and manganese in potato tubers depending on the ways of application of the soil fertiliser UGmax. J. Ecol. Eng. 18:99-106.

Braun H, Fontes PCR, Busato C, Cecon PR, 2011. Macro and micronutrient concentration and accumulation in tuber of potato cultivars as affected by nitrogen. Brag. 70:50-7.

Dabney SM, Delgado JA, Reeves DW, 2001. Using winter cover crops to improve soil and water quality. Comm. Soil Sci. Plant Anal. 32:1221-50.

Garrido AE, Strosnider WHJ, Wilson RT, Condori J, Nairn RW, 2017. Metal-contaminated potato crops and potential human health risk in Bolivian mining highlands. Environ. Geochem. Health. 39:681-700.

Griffiths AM, Cook DM, Eggett DL, Christensen MJ, 2012. A retail market study of organic and conventional potatoes (Solanum tuberosum): mineral content and nutritional implications. Int. J. Food Sci. Nutr. 63:393-401.

Hunter D, Foster M, Mcarthur JO, Ojha R, Petocz P, Samman S, 2011. Evaluation of the micronutrient composition of plant foods produced by organic and conventional agricultural methods. Crit. Rev. Food Sci. Nutrit. 51:571-82.

Hadi MR, Taheri R, Balali GR, 2014. Effects of iron and zinc fertilisers on the accumulation of $\mathrm{Fe}$ and $\mathrm{Zn}$ ions in potato tubers. J. Plant Nut. 38:202-11.

Hajšlovă J, Schulzovă V, Slanina $\mathrm{P}$, Janne K, Hellenăs KE, Andersson Ch, 2005. Quality of organically and conventionally grown potatoes: four-year study of micronutrients, metals, secondary metabolites, enzymic browning and organoleptic properties. Contain. 22:514-34.

Makarewicz A, Płaza A, Gąsiorowska B, Rosa R, Cybulska A, Górski R, Rzążewska E, 2018. Effect of manuring with undersown catch crops and production system on the potato tuber content of macroelements. J. Elem. 23:7-19.

Mengist MF, Alves S, Giffin D, Creedon J, McLaughlin MJ, Jones PW, Milbourne D, 2018. Genetic mapping of quantitative trait loci for tuber-cadmium and zinc concentration in potato reveals associations with maturity and both overlapping and independent components of genetic control. Theor. Appl. Genet 131:929-45.

Musilova J, Bystricka J, Lachman J, Harangozo L, Trebichalsky P, Volnova B, 2016. Potatoes - A crop resistant against input of heavy metals from the metallicaly contaminated soil. Int. J. Phytoremediat. 18:547-52.

Osvalde A, Karisons A, Cekstere G, Vojevode L, 2016. The effect of vermicompost-derived humic substances on nutrient status and yield of organic potato in field conditions. Acta Hort. 1142:277-83.

Płaza A, Makarewicz A, Gąsiorowska B, 2015. Influence of undersown catch crops on mineral nitrogen content determined in the soil profile in autumn and spring in conventional and organic farming systems. Fres. Envir. Bull. 10a:3315-9.

Redulla CA, Davenport JR, Evas RG, Hatterndorf MJ, Alva AK, Boydston RA, 2005. Relating potato yield and quality to field scale variability in soil characteristics. Am. J. Pot. Res. 79:317-23.

Roma A, Abete MC, Brizio P, Picazio G, Caiazzo M, D'auria JL, Esposito M, 2017. Evaluation of Trace Elements in Potatoes (Solanum tuberosum) from a Suburban Area of Naples, Italy: The "Triangle of Death". J. Food Protect. 80:1167-71.

Sawicka B, Barbaś P, Skiba D, 2016. Fluctuations of sodium, copper, zinc, iron and manganese in potato tubers in the organic and integrated production system. J. Elem. 21:539-47.

Sayed F, Hassan A, Mohamed M, 2015. Impact of bio-and organic 
fertilisers on potato yield, quality and tuber weight loss after harvest. Pot. Res. 58:67-81.

Sierra MJ, López-Nicolás R, González-Bermúdez CA, FrontelaSaseta C, Millán R, 2017. Cultivation of Solanum tuberosum in a former mining district for a safe human consumption integrating simulated digestion. J. Sci. Food Agr. 97:5278-86.

Snapp SS, Swinton SM, Labarta R, Mutch D, Black JR, Leep R, Nyiraneza J, O’Neil K, 2005. Evaluating cover crops for benefits, costs and performance within cropping system niches. Agron. J. 97:322-32.

Wang Z, Li S, Malhi S, 2008. Effects of fertilisation and other agronomic measures on nutritional quality of crops. J. Sci.
Food Agric. 88:7-23.

White P, Bradshaw JE, Dale MFB, Ramsay G, 2009. Relationship between yield and mineral concentrations in potato tubers. Hort. Sci. 44:6-11.

Wierzbowska J, Rychcik B, Światły A, 2018. The effect of different production systems on the content of micronutrients and trade elements in potato tubers. Acta Agr Scand B-S P. 68:701-8.

Wszelaki AL, Delwiche JF, Walker SD, Laggett RE, Scheerens JC, Kleinhenz MD, 2005. Sensory quality and mineral and glycoalkaloid concentrations in organically and conventionally grown redskin potatoes (Solanum tuberosum). J. Sci. Food Agric. 85:720-6. 